\title{
Stem cell tracking using iron oxide nanoparticles
}

\author{
This article was published in the following Dove Press journal: \\ International Journal of Nanomedicine \\ 3I March 2014 \\ Number of times this article has been viewed
}

\author{
Elizabeth Bull' \\ Seyed Yazdan Madani' \\ Roosey Sheth' \\ Amelia Seifalian' \\ Mark Green ${ }^{2}$ \\ Alexander M Seifalian ${ }^{1,3}$ \\ 'UCL Centre for Nanotechnology and \\ Regenerative Medicine, Division of \\ Surgery and Interventional Science, \\ University College London, London, \\ ${ }^{2}$ Department of Physics, King's \\ College London, Strand Campus, \\ London, UK; ${ }^{3}$ Royal Free London \\ National Health Service Foundation \\ Trust Hospital, London, UK
}

\begin{abstract}
Superparamagnetic iron oxide nanoparticles (SPIONs) are an exciting advancement in the field of nanotechnology. They expand the possibilities of noninvasive analysis and have many useful properties, making them potential candidates for numerous novel applications. Notably, they have been shown that they can be tracked by magnetic resonance imaging (MRI) and are capable of conjugation with various cell types, including stem cells. In-depth research has been undertaken to establish these benefits, so that a deeper level of understanding of stem cell migratory pathways and differentiation, tumor migration, and improved drug delivery can be achieved. Stem cells have the ability to treat and cure many debilitating diseases with limited side effects, but a main problem that arises is in the noninvasive tracking and analysis of these stem cells. Recently, researchers have acknowledged the use of SPIONs for this purpose and have set out to establish suitable protocols for coating and attachment, so as to bring MRI tracking of SPION-labeled stem cells into common practice. This review paper explains the manner in which SPIONs are produced, conjugated, and tracked using MRI, as well as a discussion on their limitations. A concise summary of recently researched magnetic particle coatings is provided, and the effects of SPIONs on stem cells are evaluated, while animal and human studies investigating the role of SPIONs in stem cell tracking will be explored.
\end{abstract}

Keywords: stem cells, nanoparticle, magnetic

\section{Introduction}

Stem cells are omnipotent or pluripotent cells that are characterized by their self-renewal abilities through mitotic cell division, as well as by their potential for differentiation into a range of specialized cell types. ${ }^{1}$ Their unique properties have prompted a rapidly emerging field of regenerative medicine ${ }^{2}$ whereby damaged tissues are replaced with newly derived tissues constructed or seeded from appropriately differentiated stem cells. ${ }^{3}$ In order to secure the success of this form of stem cell therapy, ${ }^{4}$ it is essential that there is a safe way to track the movement of the implanted stem cells around the body, ensuring they reach their target tissue. Recent studies have reported the imaging of stem cells using varied cell labeling techniques for the treatment of serious, debilitating diseases including ischemic stroke, ${ }^{5}$ skeletal dysplasia, ${ }^{6}$ spinal cord injury, ${ }^{7}$ and myocardial infarction. ${ }^{8}$

A popular form of high spatial resolution imaging used in stem cell studies is magnetic resonance imaging (MRI). It is non-ionizing, noninvasive, and has the ability to produce three-dimensional images. Increased accuracy in image analysis can be achieved by using contrast agents. A popular contrast agent is superparamagnetic iron oxide nanoparticles (SPIONs). SPIONs are small crystalline magnetite
Correspondence: Alexander M Seifalian UCL Centre for Nanotechnology and Regenerative Medicine,

Division of Surgery and Interventional Science, University College London, London NW3 2QG, UK

Tel +44207830290I

Email a.seifalian@ucl.ac.uk 
structures ranging in size from $5 \mathrm{~nm}$ to $150 \mathrm{~nm}^{9}$ which, when appropriately coated, become biocompatible and are readily endocytosed into the cell. They act as good contrast agents in MRI, enhancing the contrast between different tissues present by inducing a darker area (negative contrast). This is demonstrated in Figure 1, where $600 \mathrm{~nm}$ microgel iron oxide (M600) particles endocytosed into human fetal mesenchymal stem cells are imaged using transmission electron microscopy. With no cellular toxicity and a high sensitivity for MRI, M600 particles are a good candidate for use as a contrast agent in cell tracking using MRI. Additionally, SPIONs can be used for drug delivery and diagnostic purposes. Theoretically, SPIONs appear to be perfect for clinical use; however, their stability, biocompatibility, ${ }^{10}$ and ability to locate and label the cell ${ }^{11}$ must be controlled and enhanced. In this review, we explain the means of production of SPIONs and the different ways in which they are modified for specific stem cell tracking using MRI. We have also chosen to touch upon current research, both in animal and human studies that have utilized this technology, whilst discussing the potential limitations that exist.

\section{What is a superparamagnetic iron oxide nanoparticle?}

SPIONs are a form of iron oxide nanoparticle that exhibit superparamagnetism, ${ }^{12}$ a property similar to paramagnetism where a material shows magnetic properties only when under the influence of an external magnetic field. When such a field

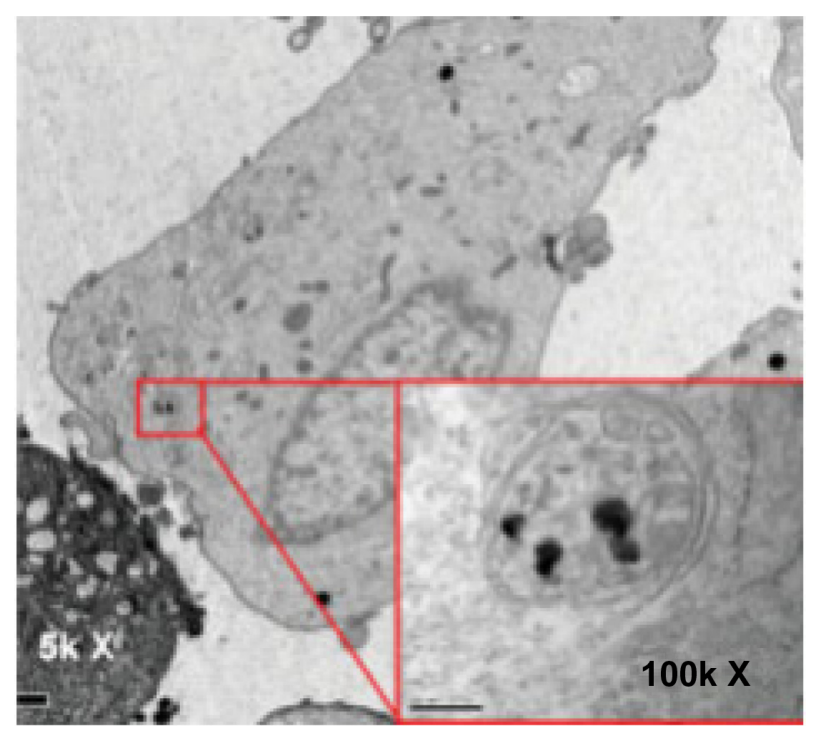

Figure I Magnetic nanoparticles imaged in the cytoplasm of a stem cell. Notes: A transmission electron microscopy image of a human fetal mesenchymal stem cell containing endocytosed microgel iron oxide particles $(600 \mathrm{~nm})$. Copyright (C) 2009 AlphaMed Press. Reproduced from Lee ES, Chan J, Shuter B, et al. Microgel iron oxide nanoparticles for tracking human fetal mesenchymal stem cells through magnetic resonance imaging. Stem Cells. 2009;27(8):1921-1931.72 is present, as is produced by an MRI machine, the magnetic moments of the nanoparticle align in the direction of the applied field. No permanent magnetism is observed, and once the magnetic field is removed, the magnetic moments of the nanoparticle returns to being randomized by Brownian motion. Superparamagnetism is a property that is favorable for imaging, as it provides a higher tendency for the material to align with an applied magnetic field and a higher magnetization of a material in response to the applied magnetic field. ${ }^{13}$ Several forms of iron oxide exist but, magnetite $\left(\mathrm{Fe}_{3} \mathrm{O}_{4}\right)$ and maghemite $\left(\gamma-\mathrm{Fe}_{2} \mathrm{O}_{3}\right)$ SPIONs are particularly common in the literature. ${ }^{14}$ Numerous studies have been conducted concerning these structures, leading to the development of many new possible applications and improvements on existing technology using SPIONs, particularly in the field of biomedicine. These ideas exploit the rare superparamagnetic properties displayed by SPIONs for imaging with MRI.

\section{Using SPIONs in magnetic resonance imaging (MRI)}

MRI is a popular noninvasive, non-ionizing imaging technique that can be used to differentiate between pathological and healthy tissues. It is a powerful imaging method that is capable of providing insight into anatomical, physiological, and molecular processes, and it is often used for the diagnosis of diseases, the study of biological functions, and to identify cancer metastasis and inflammation. ${ }^{13} \mathrm{MRI}$ is based upon the relaxation properties of hydrogen atoms in water. The human body is largely composed of water molecules, with each molecule containing two hydrogen nuclei (protons). When a patient is subjected to the powerful magnetic field generated by an MRI scanner, the magnetic moments of the protons in the water molecules align with the direction of the field. A radio frequency electromagnetic field is then briefly turned on, causing the magnetic moment of the protons to differ from that of the applied magnetic field. The electric field is then switched off and the protons "relax", returning to their original, random alignment via Brownian motion; in doing so, the protons create a radio frequency signal detected by the scanner. The technique allows for the detection of pathological tissues, such as tumors, because the protons in different tissues return to their equilibrium states at different rates. Optimizing scanner parameters or using MRI contrast agents can enhance contrast between tissues of interest, allowing for clearer imaging of specific molecules, cells, or tissues. In fact, although MRI has become one of the main imaging techniques used in oncology, its resolution is mostly insufficient at a molecular and cellular scale, unless magnetic contrast agents are employed. ${ }^{15}$ 
SPIONs are effective contrast agents, owing to their superparamagnetic properties, high relaxivity, ${ }^{16}$ and high sensitivity in MRI, which leads to the use of very low concentrations, reducing their side effects. ${ }^{17}$ When SPIONs are present, they disturb the local magnetic field homogeneity and the large susceptibility differences between the iron oxide crystals and nearby protons, leading to a rapid dephasing of surrounding protons, resulting in a decrease in transverse $(\mathrm{T} 2)^{18}$ and translational (T1) relaxation times. The shorter transverse relaxation time, in particular, results in a darker image being observed in the vicinity of the SPIONs; this is referred to as negative contrast. SPIONs have been shown to be more efficient and longer lasting than many other agents, and they importantly exhibit long blood retention times, biodegradability, and low toxicity. ${ }^{19}$ The magnetic properties of SPIONs can be manipulated by controlling the size of their core and coatings. ${ }^{20}$ The basic morphology of a SPION is a single-domain iron oxide core that is $<10 \mathrm{~nm}$ in size with a coating, which is most commonly dextran or a carboxy-dextran polymer. ${ }^{21}$ Nanoparticle aggregation can be prevented and biocompatibility improved by varying the nature of the coating applied to the core. The coating is thick compared to the core and is, therefore, the main contributor to the hydrodynamic size. The size of the particle will inevitably determine the overall chemical and physiological properties of the nanoparticle. ${ }^{22}$ A diagram of the basic structure of a magnetic nanoparticle (MNP) can be seen in Figure 2. The figure details a magnetic core which, in the context of this article, is comprised of iron oxide, a protective coating, and active molecules, bound to the coating by organic linkers. Bound active molecules (a form of surface modification) are used to tailor the nanoparticle for specific applications.

\section{Stem cell tracking}

The localization of stem cells has attracted increasing amounts of interest in the field of biomedical science in recent years due to the vast potential to revolutionize

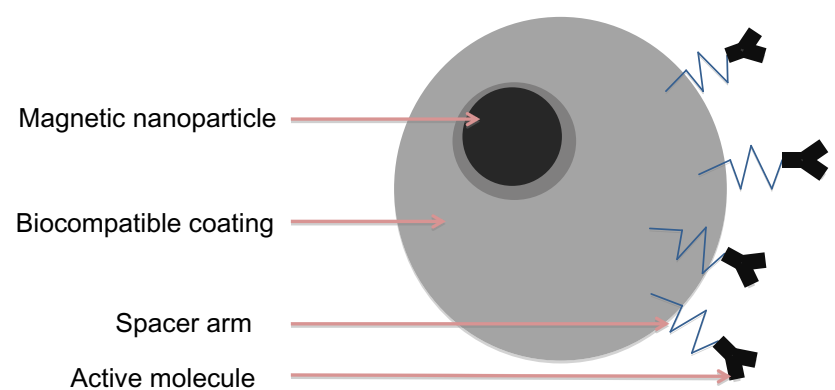

Figure 2 A basic schematic diagram of a magnetic nanoparticle's structure. Note: A magnetic nanoparticle consists of magnetic core, a protective coating, and a linker connecting active molecules. treatment for an extensive range of pathologies. To ensure that these treatments are a success, the fate of the stem cells, their functional capabilities, and the role that they play biologically must be determined. Labeling stem or progenitor cells with SPIONs allow their migration pattern to be non-invasively monitored in vivo with MRI. This has the possibility to help monitor stem cell therapy in the treatment of diseases such as myocardial infarctions, ${ }^{23}$ neurological diseases, and cancer. ${ }^{24}$ Success has recently been reported in a rat model of Huntington's disease. ${ }^{24}$ Figure 3 shows an MRI of SPION-labeled mesenchymal stem cells (MSCs) in vivo, which could be imaged 60 days post-implantation. The labeled MSCs showed no sign of reduced cell viability, proliferation, or differentiation and, importantly, the number of degenerating neurons was reduced. This was ascertained by using techniques developed in previous research by Jasmin et al, ${ }^{25}$ which included use of a live/dead viability/toxicity kit. The results showed that while, on its own, MRI imaging can only really highlight the position of stem cells in the body, combing techniques such as computed tomography, positron emission tomography, ${ }^{26}$ single-photon emission computed tomography, and optical imaging provide a wide array of data, which could be gathered to present a clearer picture of biodistribution differentiation, cell viability, and function. ${ }^{27}$
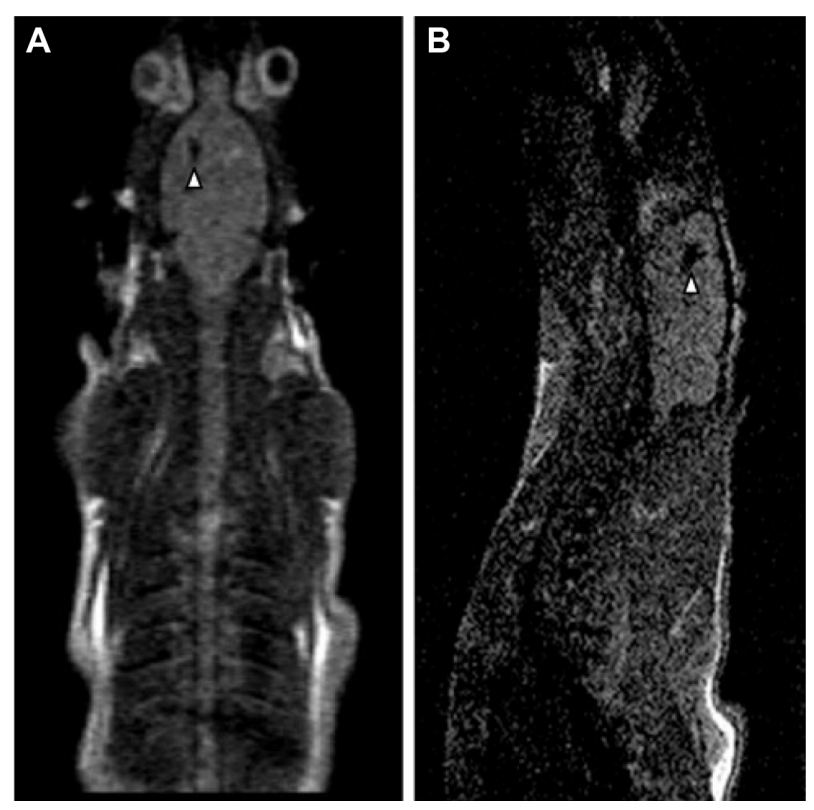

Figure 3 Magnetic resonance imaging (MRI) of rats with neurodegenerative disease injected by mesenchymal stem cells labeled with magnetic nanoparticles.

Notes: In both MRI images (sagittal A and horizontal B) a dark area, identified by a white arrow, is present. This indicates a large concentration of SPION-labeled mesenchymal stem cells. Reprinted from Stem Cell Res, 9(2), Moraes L, Vasconcelosdos-Santos A, Santana FC, et al, Neuroprotective effects and magnetic resonance imaging of mesenchymal stem cells labeled with SPION in a rat model of Huntington's disease, 143-155, Copyright (2012), with permission from Elsevier. ${ }^{21}$ 
The future for the use of SPIONs in stem cell tracking is hopeful. In theory, information gained from stem cell tracking could lead to optimized dosages, preferred sites of engraftment, and specialized timing of stem cell injections, ${ }^{28}$ allowing for the tailoring of treatments to individual patients.

Although the future is promising, if the tracking of SPION-labeled stem cells is to gain widespread use in clinical cellular therapies, it is essential to explore:

1. different coatings used to form biocompatible and longlived SPIONs;

2. the synthesis of the chosen coated SPIONs;

3. uptake of SPIONs into specific stem cells; and

4. the limitations involved in SPION stem cell tracking.

In this review, we will cover these topics, providing a clear understanding of the processes involved in stem cell tracking using SPIONs.

\section{Synthesis and labeling of magnetic iron oxide particles}

Many different chemical methods for synthesizing MNPs are available, including thermal decomposition, hyperthermal, coprecipitation, solvo-thermal route, and sol-gel methods. Most commonly used is the precipitation-based approach, which is achieved either by coprecipitation or reverse micelle synthesis. This is shown in Table 1, which outlines the various research groups who showed that decomposition methods can produce MNPs with more favorable magnetic properties when compared to those formed by coprecipitation. The choice of the core of the MNP is an important factor when producing MNPs. The majority of the studies detailed in Table 1 use iron oxide, due to its biocompatibility and low toxicity. Iron oxide nanoparticles without a surface coating are not viable in aqueous medium and, therefore, will readily aggregate and precipitate.

In vivo experimental results show that particles will form aggregates in the blood, resulting in unwanted sequestration by macrophages. ${ }^{29}$ In order to counteract this effect, the surface of SPIONs has been functionalized to enhance biocompatibility. Table 2 details many of the coatings used in the literature and the effect that they have on the nanoparticle. The process of nanoparticle coating can be achieved by different mechanisms. Two common methods of doing so include:

1. in situ coatings whereby the SPION is coated during the process of synthesis and post-synthesis; ${ }^{28}$ and

2. liposome encapsulation to create magnetoliposomes, adding a more hydrophobic nature to the particle. ${ }^{30}$
After coating, the SPION can be used to label the cells. This is achieved by one of two methods:

1. Attaching the nanoparticle to the surface of the stem cell.

2. Internalizing the biocompatible SPION by endocytosis or phagocytosis.

It is important to note that the first method, surface labeling, is limited to in vitro settings, as the method is generally unsuitable for use in vivo models due to clearance of the labeled cells from rapid reticuloendothelial recognition. ${ }^{31}$ In the internalization method, the SPION can enter the cell via either receptor-mediated interactions or nonspecific internalization pathways.

In both cases, the nanomaterials become entrapped within the endosomes and are released into the cytoplasm. Human stem cells, such as mesenchymal stem cells, can internalize nanoparticles, even in the absence of transfection agents. ${ }^{32}$ In most cases, however, the internalization of the SPION requires the use of an inactive substance that can be used as a carrier for an active ingredient, also known as an excipient. ${ }^{15}$

\section{A comparison of different coats for SPIONs}

The success of labeling stem cells with SPIONs is usually advanced by encasing the nanoparticle in a biocompatible coating. The correct choice of coating will ensure stability, solubility, and prevent aggregation of the SPIONs. Often a transfection agent is used, which promotes a quicker and significantly more efficient uptake of the label into the cell. Some common examples are poly-L-lysine (PLL), sulfate, and protamine. ${ }^{29}$ It is important to not only choose the correct coating, but also to use the correct concentration of the transfection agent. This is highlighted in Figure 4, in which protamine is used as a transfection agent for the MNP, Feridex (Ad-Vance Magnetics Inc, Rochester, IN, USA). At a low concentration $(1 \mu \mathrm{g} / \mathrm{mL})$ of protamine, a lower percentage of mesenchymal stem cells are labeled than at the recommended concentration of protamine $(5 \mu \mathrm{g} / \mathrm{mL})$, in which $95 \%$ of the cells are labeled. After a transfection agent has been applied, the nanoparticles are incubated overnight in the appropriate stem cell medium, which facilitates a passive uptake of the nanoparticles. Notable and interesting exceptions are epithelial cell adhesion molecule beads, which utilize antigens that are specifically present on the human hepatic stem cells. Exterior attachment of the label is achieved by specific antibodies manufactured on the surface of the nanoparticle, which are complimentary to the antigen on the human hepatic 


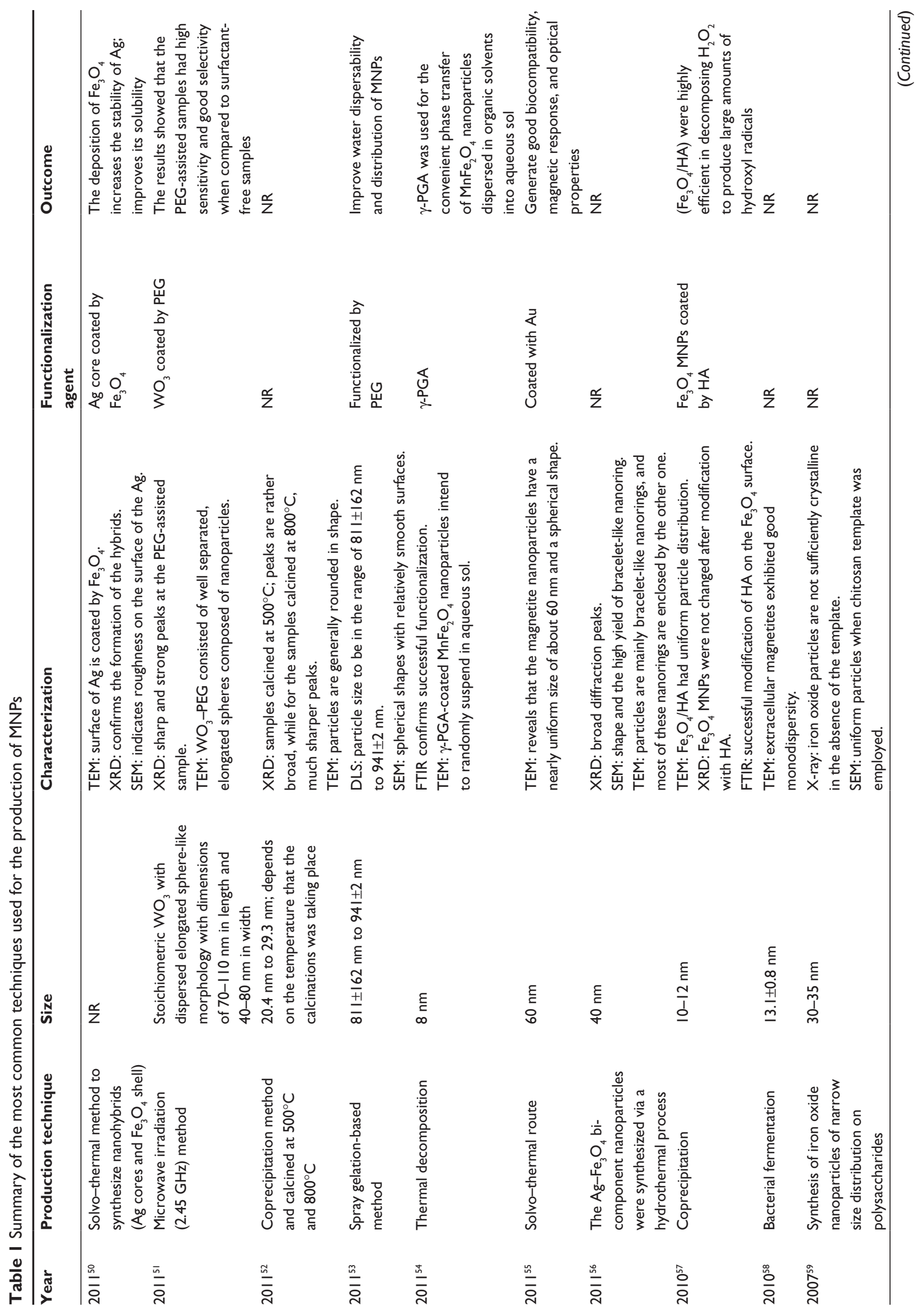




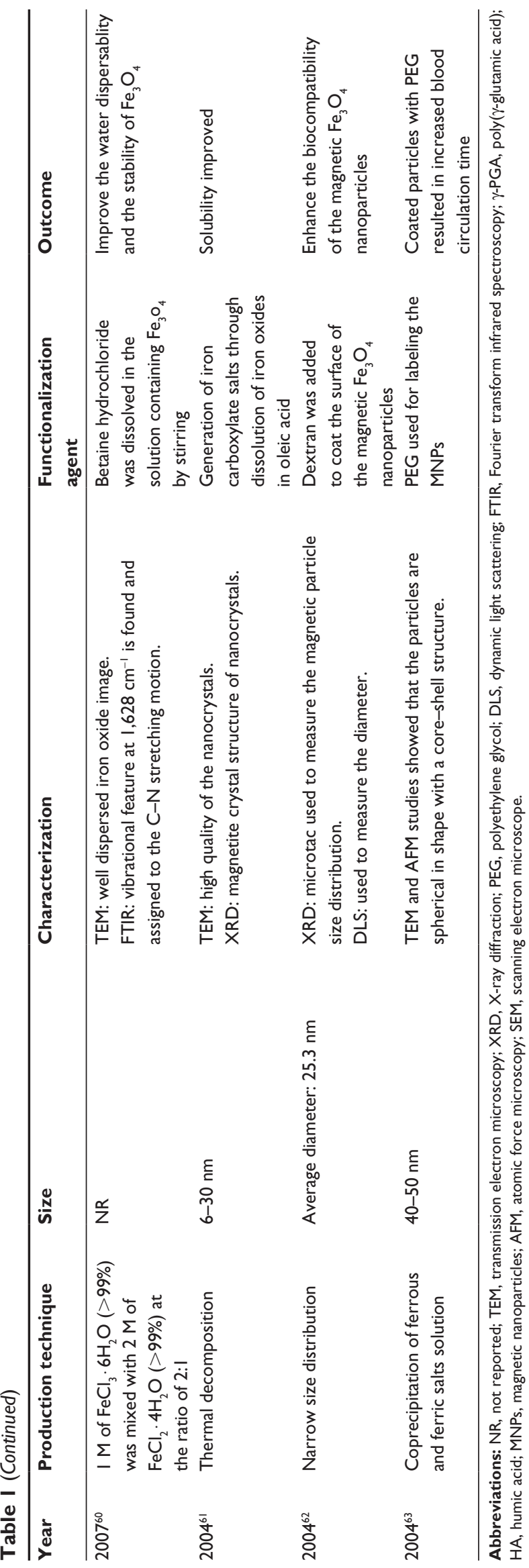

stem cells. The usual process of passive uptake is often close to being $100 \%$ successful, meaning that in general, the labels are evaluated by the effect that they have on stem cells, their relaxivity, and the time in which they remain detectable by MRI. ${ }^{33}$

A wide array of different nanoparticles and coatings has been reported in the literature with impressive results. ${ }^{33}$ For the most part, ferumoxide, ferucarbotran, and Feridex SPIONs coated with different materials (such as dextran and carboxydextran) are used, as they are approved for human use. A specific example of human use is shown in Figure 5, in which neural stem cells are labeled by the nanoparticle, Feridex, which is coupled to the transfection reagent, Effectene $^{\circledR}$ (Qiagen, Venlo, the Netherlands). A lesion in the left temporal lobe is highlighted with an asterisk and no signal is seen (Figure 5A) on the MRI image before the implantation of the labeled stem cell. One day later, implantation signals were observed (Figure 5B), indicating the presence of the labeled neural stem cells at the legion site. A clear, concise summary of the effect of some commonly used magnetic nanoparticles is given in Table 2. The method of labeling, the percentage of the cells labeled, how long the label remains in the cell, and the effect of the presence of the label in the cell is detailed. Other nanoparticles have been tested and evaluated as MRI contrast agents (for example, gold, $\mathrm{MnO}$, and $\mathrm{CoPt}$ ); however the sheer volume of literature available regarding coated SPIONs confirms their superiority as a contrast agent in the field of stem cell tracking.

\section{In vivo animal studies}

The in vivo tracking of stem cells using SPIONs has already been extensively studied in various animal models. Jing et al, ${ }^{34}$ using the Feridex-protamine sulfate complex as the SPION, as well as transfection agents, tracked mesenchymal stem cells in the articular cartilage within the knee joints of rabbits. The study showed that there were no changes in the viability, proliferation, or differentiation of the labeled stem cells in comparison to the non-labeled cells when examined at a concentration of $25 \mu \mathrm{M}$. Once the labeled stem cells were intra-articularly injected, upon gradient echo sequence-T2 weighted signals, areas of hypointense signals could be seen on imaging and were apparent for at least 12 weeks after the initial injection. Comparable results were also seen in a study by Hu et al, ${ }^{35}$ in which human umbilical cord mesenchymal stem cells were transplanted surgically into the spinal cord of an adult rat. Once again, the researchers used Feridex coating for the SPION, at $22.4 \mu \mathrm{g}$ coating for the SPION on a gradient echo sequence-T2 weighted MRI, there was 
a markedly hypointense area in the region transplanted with SPION-labeled human umbilical cord mesenchymal stem cells and, more importantly, that the transplanted labeled cells were found to be more hypointense than non-labeled cells. It was also determined that the stem cells were accurately detectable 2 weeks after the initial transplant. It is, furthermore, important to note that both Jing et $\mathrm{a}^{134}$ and $\mathrm{Hu}$ et al ${ }^{35}$ identified that the extent of the signal intensity changes expressed by SPION-labeled stem cells was dependent on the number of labeled stem cells at any one time, and that this number could decrease significantly over time. The role of stem cells in myocardial repair following myocardial infarction or insult has yet been established.

A study by Amsalem et al ${ }^{47}$ used SPIONs, coated with ferumoxide and complexed to PLL, to track MSC after being injected into the rats, 7 days after inducing a myocardial infarction. The authors found that after 1 week, 2 weeks, and 4 weeks, the MRI demonstrated well-defined hypointense areas in the rats that were injected with SPION-labeled MSCs, while control specimens injected with saline or unlabeled MSCs showed no areas of hypointensities. There was retention of the magnetic signal throughout the 4-week period, and this was comparable among both groups of rats (those that had suffered a myocardial infarction, and those that had not). Another group of researchers, Chapon et al, ${ }^{36}$ used dextran-coated SPIONs to track bone marrow-derived mesenchymal stem cells to determine their effect in host cardiac tissue after a myocardial infarction. It was shown that the SPION-labeled stem cells could be tracked for up to 6 weeks after the initial stem cell injection using MRI. In addition, the study also demonstrated that there was a larger uptake of stem cells in infarcted tissue, as shown by the positron emission tomography study, in which radiolabeled glucose (2-deoxy-2-[F-18] fluoro-D-glucose [FDG]) was used to determine glucose uptake of the cells at the infarcted areas. While the study showed that despite the increased uptake of bone marrow-derived mesenchymal stem cells in the infarcted areas there was no improved left ventricular function in the rats, it did highlight the ability to track the stem cells. Although promising, some limitations and questions arose from the research concerning the best medium and cell surface coating to use in order to optimize stem cell tracking, and as such, further in vivo work would need to be conducted.

Further research conducted by Delcroix et $\mathrm{al}^{37}$ in 2009 investigated how stem cell tracking in neural migratory pathways could be potentially used for clinical therapy. The researchers used SPIONs, which were coated with 1-hydroxyethylidene-1.1-bisphosphonic acid to label rat mesenchymal stem cells. ${ }^{37}$ It had already been established that in an appropriate environment, which contains particular matrix molecules and growth factors, mesenchymal stem cells were able to transdifferentiate into neural cells in vitro, though very little work had been done in vivo. Delcroix et $\mathrm{al}^{37}$ incubated the rat mesenchymal stem cells (rMSCs) for 48 hours with $50 \mathrm{ug} / \mathrm{mL}$ of 1-hydroxyethylidene-1. 1-bisphosphonic acid (HEDP)-coated SPIONs. They established that there was no effect or change in the morphology or viability of the rMSCs. At this point, it was discovered that by using an MRI, there was a long distance of migration in rMSC from the subventricular zone to the olfactory bulb via the rostral migratory system. The value of the research conducted by Delcroix et $\mathrm{al}^{37}$ demonstrated for the first time that neural migratory pathways can be established and mapped out using SPIONs. The importance of identifying stem cell migratory mechanisms in response to injury could eventually lead to the use of MSCs in brain cell therapy, and it further establishes that additional research is required as to why, despite in vitro models suggesting that transdifferentiation of MSCs into neural cells, this is not the case in vivo. There is considerable promise and established research that demonstrates that SPIONs have an exciting role in stem cell tracking by non-invasive mechanisms which could, in time, lead to deeper appreciation of tissue regeneration pathways and future clinical applications.

\section{Human studies}

There is a great potential role for the in vivo, non-invasive tracking of transplanted human stem cells, as there is scope for obtaining real-time insights into underlying physiological and cellular responses of stem cells in both normal functioning and pathological injury. As was discussed with the animal studies, understanding migratory pathways and the manner in which different stem cells differentiate to site-specific cells can be crucial in the development of clinical therapies. In order for long-term clinical therapies to be introduced, there is a necessary evolution in research that has to occur, as animal models need to progress to human models before clinical trials can take place.

It is important to take into account the variable factors that make clinical trials on humans more challenging than simply repeating an experiment, as deduced from research on animal models. For example, the organism's weight, blood volume, cardiac output, and intra- as well as inter-cellular microenvironments are markedly different from one animal to another; as such, human studies would require careful 
Table 2 An analysis of the MNPs for their use in stem cell tracking using MRI

\begin{tabular}{|c|c|c|c|c|}
\hline Year & Type of MNP & $\begin{array}{l}\text { How stem cells attached } \\
\text { to SPIONs }\end{array}$ & $\begin{array}{l}\text { Method of production } \\
\text { of label }\end{array}$ & Clinical application \\
\hline $2011^{48}$ & $\begin{array}{l}\text { Gold nanoparticle coated } \\
\text { with PLL or citrate solution }\end{array}$ & $\begin{array}{l}\text { Passive uptake of the } \\
\text { nanoparticles by the cells }\end{array}$ & $\begin{array}{l}\text { Gold nanoparticles coated } \\
\text { with PLL added to cell culture } \\
\text { and incubated for } 24 \text { hours }\end{array}$ & $\begin{array}{l}\text { MSC labeling, imaging, and } \\
\text { tracking }\end{array}$ \\
\hline $2011^{32}$ & USPIO-PS & $\begin{array}{l}\text { Passive uptake of the } \\
\text { nanoparticles by the cells }\end{array}$ & $\begin{array}{l}\text { USPIOs are composed of } \\
\text { maghemite cores modified on } \\
\text { their surface by amino silane } \\
\text { coupling agents }\end{array}$ & $\begin{array}{l}\text { Labeling of hADSCs to assess } \\
\text { their fate in vivo on a three- } \\
\text { dimensional, porous scaffold }\end{array}$ \\
\hline $2011^{65}$ & FE-Pro & $\begin{array}{l}\text { Passive uptake of the } \\
\text { nanoparticles by the cells }\end{array}$ & $\begin{array}{l}\text { Ferumoxide-protamine sulfate } \\
\text { complex was made with } \\
\text { ferumoxides mixed with } \\
\text { protamine sulfate solution }\end{array}$ & $\begin{array}{l}\text { Labeling hB MSCs with FE-Pro } \\
\text { to be tracked by MRI }\end{array}$ \\
\hline $2011^{66}$ & $\begin{array}{l}\text { Mesoporous silica-coated } \\
\text { hollow manganese oxide } \\
\left(\mathrm{HMnO@mSiO}_{2}\right) \\
\text { nanoparticles }\end{array}$ & Electroporation & $\begin{array}{l}\text { MnO nanoparticles were } \\
\text { prepared, stabilized, and coated } \\
\text { with a silica coating }\end{array}$ & $\begin{array}{l}\text { MRI tracking of } \mathrm{MSC} \text { using } \\
\mathrm{HMnO} @ \mathrm{mSiO}_{2} \text { as a positive } \\
\text { marker }\end{array}$ \\
\hline $2011^{67}$ & CoPt hollow nanoparticles & $\begin{array}{l}\text { Passive uptake of the } \\
\text { nanoparticles by the cells }\end{array}$ & $\begin{array}{l}\text { CoPt nanoparticles were } \\
\text { synthesized and coated with a } \\
\text { mixture of PEG-SH and CCALNN } \\
\text { peptide }\end{array}$ & $\begin{array}{l}\text { MRI tracking of grafted NSCs } \\
\text { labeled with CoPt }\end{array}$ \\
\hline $2009^{68}$ & $\begin{array}{l}\text { SPIONs with a } \\
\text { carboxydextran coating }\end{array}$ & $\begin{array}{l}\text { Passive uptake of the } \\
\text { nanoparticles by the cells } \\
\text { by endoplasmic absorbtion }\end{array}$ & $\begin{array}{l}\text { MSCs culture medium was } \\
\text { incubated for } 24 \mathrm{~h} \text { with } \\
\text { Ferucarbotran }\end{array}$ & $\begin{array}{l}\text { Labeling and therefore } \\
\text { tracking MSCs in the kidney } \\
\text { of a dog }\end{array}$ \\
\hline $2009^{69}$ & $\mathrm{SPIO} @ \mathrm{SiO}_{2}-\mathrm{NH}_{2}$ & $\begin{array}{l}\text { Passive uptake of the } \\
\text { nanoparticles by the cells }\end{array}$ & $\begin{array}{l}\text { Polyhedral crystalline SPIO } \\
\text { nanoparticles were prepared } \\
\text { by a coprecipitation method }\end{array}$ & $\begin{array}{l}\text { Tracking MSCs using SPIO@ } \\
\mathrm{SiO}_{2}-\mathrm{NH}_{2} \text { with MRI }\end{array}$ \\
\hline $2010^{70}$ & $\begin{array}{l}\text { Chitosan-SPIONs } \\
\text { coated in PLL }\end{array}$ & $\begin{array}{l}\text { Passive uptake of the } \\
\text { nanoparticle by the cells } \\
\text { using endocytosis }\end{array}$ & $\begin{array}{l}\text { Chitosan-SPIO synthesized by a } \\
\text { sono-chemical method followed } \\
\text { by a chitosan coating process }\end{array}$ & $\begin{array}{l}\text { Label and track hBM-MSC } \\
\text { using MRI }\end{array}$ \\
\hline $2007^{60}$ & MGIO & $\begin{array}{l}\text { Passive uptake of the } \\
\text { nanoparticles by the cells } \\
\text { via endocytosis }\end{array}$ & $\begin{array}{l}\text { Nonmagnetic PMG synthesized } \\
\text { then magnetized by the } \\
\text { coprecipitation of iron salt to } \\
\text { form primary iron oxide cores } \\
\text { within PMG }\end{array}$ & $\begin{array}{l}\text { Labeling hfMSCs for MRI } \\
\text { tracking with MGIO }\end{array}$ \\
\hline $2009^{71}$ & $\begin{array}{l}\text { SPION coated } \\
\text { with starch }\end{array}$ & Passive uptake by the cells & $\begin{array}{l}\text { SPIONs coated in starch were } \\
\text { synthesized. } \\
\text { Incubation with nanoparticles in } \\
\text { the cell culture medium }\end{array}$ & $\begin{array}{l}\text { Labeling and tracking MSCs } \\
\text { using SPIONs }\end{array}$ \\
\hline
\end{tabular}

Abbreviations: MNPs, magnetic nanoparticles; MRI, magnetic resonance imaging; SPIONs, superparamagnetic nanoparticles; PLL, poly-L-lysine; MSC, mesenchymal cells; NR, not reported; USPIO-PS, ultrasmall superparamagnetic iron oxide; hADSCs, human adipose-derived stem cells; FE-PRO, ferumoxide-protamine sulfate complex; hB, human bone; CoPt, cobalt platinum; PEG-SH, polyethylene glycol; CCALNN, cysteine-cystein-alanine-leucine-asparagine; NSC, neural stem cells; SPIO, superparamagnetic iron oxide; MGIO, microgel iron oxide; PMG, precursor microgel; hfMSC, human fetal mesenchymal cells.

planning and assurance of safe testing before moving ahead. ${ }^{38}$ Although only a few studies have been done, research has indeed showed that there is effective non-invasive tracking of labeled human embryonic stem cells using MRI imaging. The first study that attempted clinical MRI tracking of therapeutic cells in humans was first reported in $2005 .{ }^{39}$ The researchers co-cultured immature dendritic cells with 200 $\mu \mathrm{g} / \mathrm{ml} \mathrm{SPION} .^{39}$ They confirmed that the dendritic cells had taken up a significant amount of SPION before the end of the culture period. Following intranodal injection into eight grade 3 melanoma patients, 3T MRI along with scintigraphy was used to image the injected cells. The results showed that MRI imaging was at least as sensitive an imaging modality as scintigraphy, and it also managed to track the cells with a higher degree of accuracy due to its superior spatial resolution. de Vries et $\mathrm{al}^{39}$ noted in their work that $50 \%$ of the ultrasoundguided injections of stem cells were misadministered into nodes adjacent to the target lymph node and, importantly, this was only revealed on subsequent MRI imaging. Identifying this error, however, showed that SPION-labeled cells could be tracked using MRI, and they could also be used to ensure that cells are injected or delivered to the correct target site. In 2008, Zhu et $\mathrm{al}^{40}$ conducted a case study on two patients: one of which was a 34-year-old man who had brain trauma 


\begin{tabular}{|c|c|c|c|c|}
\hline In vivo/in vitro & $\begin{array}{l}\% \text { of stem cells } \\
\text { labeled }\end{array}$ & Effect on stem cells & $\begin{array}{l}\text { How long the label } \\
\text { remained detectable }\end{array}$ & Other \\
\hline $\begin{array}{l}\text { In vitro (LIVE/ } \\
\text { DEAD stain) }\end{array}$ & NR & $\begin{array}{l}\text { Not cytotoxic to the cells and did } \\
\text { not substantially affect viability }\end{array}$ & NR & $\begin{array}{l}\text { Cell uptake of the } \\
\text { nanoparticle decreased }\end{array}$ \\
\hline Mouse & $91 \%$ & $\begin{array}{l}\text { Not toxic for the cells apart from } \\
\text { a slight loss of metabolic activity at } \\
\text { days II and I } 4 \text { compared to the } \\
\text { unlabelled cells }\end{array}$ & $\begin{array}{l}28 \text { days after } \\
\text { implantation }\end{array}$ & $\begin{array}{l}\text { USPIO allowed the } \\
\text { visualization of } 5 \times 10^{4} \\
\text { labeled hADSCs by MRI }\end{array}$ \\
\hline Ex vivo & $95 \%$ & $\begin{array}{l}\text { Did not harm cells or influence their } \\
\text { behavior, including viability, long- } \\
\text { term metabolic cell activity }\end{array}$ & NR & $\begin{array}{l}\text { Transfection with protamine } \\
\text { sulfate leads to a higher } \\
\text { uptake }\end{array}$ \\
\hline Mouse & $\begin{array}{l}26 \% \text { with } \\
\text { electroporation }\end{array}$ & Minimal impact on cell viability & 14 days & $\begin{array}{l}\text { Significantly higher relativity } \\
\text { versus existing manganese } \\
\text { oxide nanoparticles }\end{array}$ \\
\hline In vitro & NR & $\begin{array}{l}\text { No impact on cell viability, } \\
\text { morphology, or proliferation at low } \\
\text { concentrations of CoPt nanoparticles }\end{array}$ & $\begin{array}{l}\text { Detectable at low cell } \\
\text { numbers with MRI } \\
\text { after } 2 \text { weeks }\end{array}$ & $\begin{array}{l}\text { Optimized when NSCs } \\
\text { exposed to } 8 \mathrm{mg} \mathrm{mL}^{-1} \text { and } \\
16 \mathrm{mg} \mathrm{mL}^{-1} \text {, and CoPt for } \\
48 \text { hours }\end{array}$ \\
\hline Dog & $\begin{array}{l}\text { PLL coating } \\
\text { Has a higher labeling } \\
\text { efficiency than ferumoxide }\end{array}$ & $\begin{array}{l}\text { Impaired viability and/or apoptosis } \\
\text { at higher conc. } \\
\text { No affect on cell viability and } \\
\text { proliferation }\end{array}$ & NR & $\begin{array}{l}\text { Can label efficiently without } \\
\text { transfer agent }\end{array}$ \\
\hline Rabbit & $\begin{array}{l}\text { Increased MSC- } \\
\text { labeling effects }\end{array}$ & $\begin{array}{l}\text { Displayed normal nuclear } \\
\text { morphology, apoptosis, and necrosis } \\
\text { changes were not observed }\end{array}$ & 12 weeks & NR \\
\hline Rabbit & Almost $100 \%$ & $\begin{array}{l}\text { Did not show any cytotoxicity up to } \\
\text { a } 200 \mathrm{mg} \mathrm{Fe} / \mathrm{mL} \text { concentration }\end{array}$ & 2 weeks & NR \\
\hline Rat & $97 \%$ & $\begin{array}{l}\text { There was no affect on cellular } \\
\text { proliferation }\end{array}$ & $\begin{array}{l}\text { M600 particles could } \\
\text { be detected even after } \\
\text { four cellular divisions }\end{array}$ & $\begin{array}{l}\text { M600 achieved a five- to } \\
\text { sevenfold higher sensitivity } \\
\text { for MRI detection than } \\
\text { ferucarbotran }\end{array}$ \\
\hline NR & $\begin{array}{l}\text { Uptake was } \\
\text { proven but not } \\
\text { quantified }\end{array}$ & $\begin{array}{l}\text { Cells able to differentiate into } \\
\text { stromal tissue, including bone and } \\
\text { fat }\end{array}$ & $\begin{array}{l}28 \text { days; could visualize } \\
\text { I,000 MSCs }\end{array}$ & $\begin{array}{l}\text { No MRI signal with the use } \\
\text { of free iron- or dead iron- } \\
\text { labeled MSCs }\end{array}$ \\
\hline
\end{tabular}

in his left temporal lobe in 2004; and a control 42-year-old male who had brain trauma in his right temporal lobe. Neural tissue from both patients was taken during emergency operations, and the test patient had his neural tissue incubated with Feridex SPIONs and a lipofection transfection agent. ${ }^{40}$ The SPION-labeled neural stem cells were then injected around the region of the brain damage and 3T MRI was performed at 24 hours, then every 7 days after transplantation for 10 weeks. Before implantation, upon T2 weighted MRI imaging, no pronounced hypointense signals were found, although the injection sites themselves produced a circular area of dark tissue on imaging. This hypointense signal at the injec- tion sites faded after a week or so. In terms of the injected cells themselves, a hypointense signal was seen around the border of the damaged tissue in the temporal lobe, and it intensified at around weeks 2 and 3, before eventually fading after 7 weeks, most likely due to dilution of the SPIONs in response to cell proliferation around the site of the lesion. In the control patient, however, there was no change in the signal on MRI during the observation over the trial period, although there was a slight hypointense signal at the injection sites. The researchers concluded that stem cell migration after implantation could indeed be detected via non-invasive methods using SPIONs and MRI. 

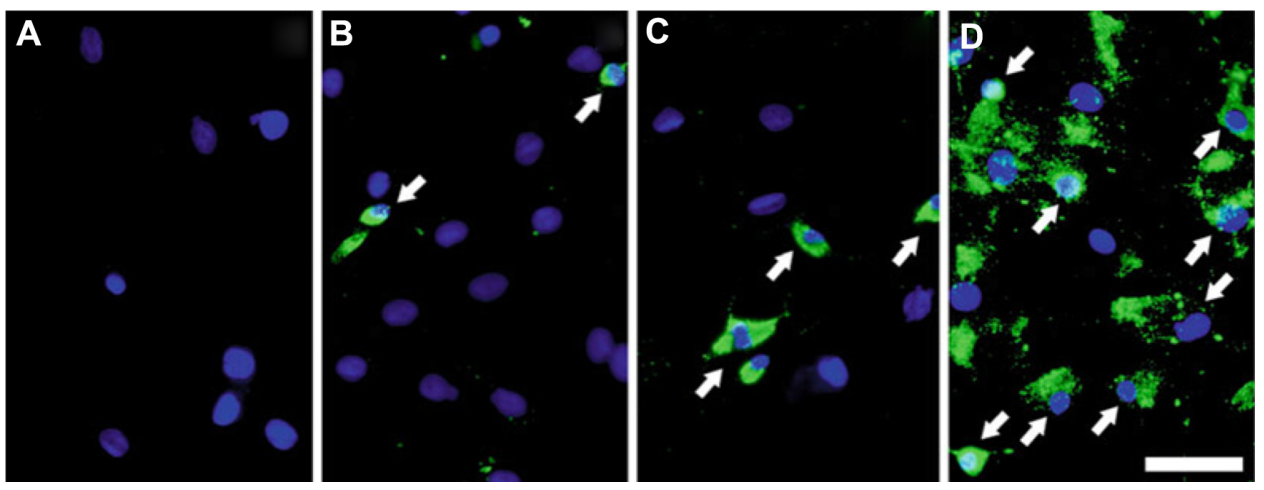

Figure 4 Application of transfection agents to encourage a swift uptake of magnetic nanoparticles by stem cells.

Notes: Conjugating protamine to magnetic nanoparticles (Feridex; Ad-Vance Magnetics Inc, Rochester, IN, USA) significantly improved the uptake of the nanoparticles by the mesenchymal stem cells. The nuclei of the stem cells are labeled in blue, with white arrows identifying some of the magnetically labeled cells; the superparamagnetic iron oxide nanoparticles were detected using anti-dextran antibodies. The image shows the mesenchymal stem cells with protamine only (A), with magnetic nanoparticles in the absence of protamine (B), and with magnetic nanoparticles of a protamine at concentrations of I $\mu \mathrm{g} / \mathrm{mL}$ (C) and $5 \mu \mathrm{g} / \mathrm{mL}$ (D). Scale bar is $50 \mu \mathrm{m}$. Springer and Methods Mol Biol, 906, 2012, 239-252, Labeling stem cells with superparamagnetic iron oxide nanoparticles: analysis of the labeling efficacy by microscopy and magnetic resonance imaging, Jasmin, Torres AL, Jelicks L, de Carvalho AC, Spray DC, Mendez-Otero R, Figure 2. ${ }^{29}$ With kind permission from Springer Science and Business Media.

As of yet, not many human subject studies have been done using SPIONs, but even from the brief research that has been conducted, there seems to be legitimate and effective results showing the promising use of SPIONs in stem cell tracking using non-invasive mechanisms, such as MRI. Of course, dependent on the progress of work in animal models, human studies can progress. Much will still need to be done to obviate the use of transfection agents, which may be attributed to cell death, and to assess the most appropriate and suitable method of labeling stem cells.

\section{The limitations of MRI and the use of SPIONs}

The limitations of MRI are well illustrated in their use of stem cell tracking. First, due to cell division, the SPIONlabeled cells become diluted in a localized site and, consequently, the generated image is weakened or distorted. This
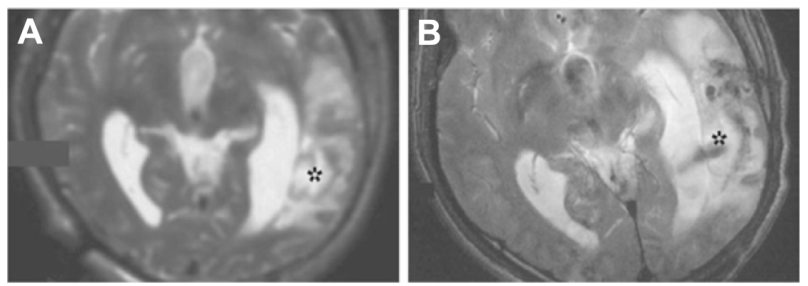

Figure 5 Magnetic resonance imaging scan of the damaged temporal lobe of a human that received neural stem cells labeled with magnetic nanoparticles.

Notes: The magnetic resonance images show pre- (A) and post-implantation (B) of neural stem cells into the temporal lobe. The stem cells are labeled with the magnetic nanoparticle, Feridex (Ad-Vance Magnetics Inc, Rochester, IN, USA), coupled to a transfection reagent. No signal was detected at the lesion, labeled with an asterisk, before the injection; however, I day post-injection, a dark area was seen around the lesion, indicating the presence of the magnetic-labeled neural stem cells. Copyright (C) 20II. John Wiley and Sons, Inc. Reproduced from Cromer Berman SM, Walczak P, Bulte JW. Tracking stem cells using magnetic nanoparticles. Wiley Interdiscip Rev Nanomed Nanobiotechnol. 20I I;3(4):343-355. ${ }^{33}$ has been seen in neural stem cells where the concentration of SPIONs was shown to decrease by $50 \%$ every 3 days in vitro. Second, due to the in vivo migration of SPIONlabeled stem cells, the density of the cells is considerably reduced over time, again leading to a weakening of the MRI signal. ${ }^{24}$ Third, SPION cell labeling itself cannot determine if or what the SPION-labeled stem cell differentiates into, although through the use of combined imaging techniques such as immunohistochemistry and confocal microscopy, the function of the stem cell can be ascertained ${ }^{41}$ Fourth, most studies utilizing MRI are conducted with a 1.5T MRI unit, which has a limited spatial resolution and does not allow for deep imaging. An improvement in spatial resolution can only be achieved through the use of stronger magnetic fields, and it is still unknown what effect this would have upon the cells. ${ }^{42}$ Fifth, SPIONs are not detected directly; rather, they are detected through indirect microscopic disturbances in the magnetic field. As a result of this, it proves harder to correlate the magnetic resonance signal with the number of cells present. ${ }^{43}$ Another commonly encountered problem is that if cells die, they will still be imaged by MRI, as the SPIONs will remain inside or attached to the cell. This invariably leads to an inaccurate analysis of the MRI image, especially since it is likely that these dead cells are engulfed by macrophages, which would lead to contrast agents being present in the lymph nodes.

SPIONs come with an inherent risk of toxicity, as is the case with any foreign particle or chemical that is injected or administered within an organism. SPIONs are composed of biodegradable iron, which could potentially be recycled by cells within the body that use biochemical pathways for iron metabolism. This would lead to a situation of iron-mediated 
toxicity, which includes the synthesis of iron-catalyzed reactive oxygen species. ${ }^{44}$ The cytotoxicity of SPIONs has been explored in human mesenchymal stem cells, ${ }^{42}$ mouse embryonic stem cells, ${ }^{23}$ and neural stem cells ${ }^{45,46}$ by a variety of researchers. It was discovered that on the whole, the internalization of the nanoparticle into these stem cells did not affect cell growth or differentiation or, indeed, its viability to survive. However, there has been evidence to suggest that endocytic lifecycles can be affected due to nanoparticles residing in endosomes. ${ }^{45}$ Studies were undertaken, which showed that it is the iron itself within the SPION that caused impairment in chondrogenic differentiation, as opposed to any transfection factors that were present; ${ }^{46-48}$ however, other research shows that it is the transfection agent, PLL, that causes this effect on differentiation (for more toxicity information, see Table 2). The application of SPIONs in medicine brings a new dimension into monitoring stem cells in vitro and in vivo. It will allow for groundbreaking research or therapeutic achievements. However, it is important that with the huge potential of this ability to manipulate size, shape, charge, or surface modification, detailed studies of toxicity are carried out and cell damage with SPIONs checked before clinical application. For example, configuration of SPIONs into different shapes such as spheres, nanoworms, rod shapes, or beads for different functional applications may increase toxicity. This was demonstrated with mouse L929 fibroblast cells; there was significant increased toxicity, despite being at the same molarity as other configurations, when the cells were exposed to nanobeads, nanoworms, or nanospheres. ${ }^{49}$ This helps to highlight different physicochemical properties such as final size, shape, and charge, which will affect the viability of SPIONs. As such, it is imperative that further detailed toxicity testing is undertaken to assess SPION toxicity and to be aware that new surface modification may alter the toxicity of the nanoparticles.

\section{Conclusion}

Stem cell therapy has boundless scope and prospects for therapeutic and clinical use. In this review, we have focused on stem cell tracking using SPIONs. We have discussed and evaluated the way in which SPIONS are synthesized, coated, and targeted for the use in stem cell tracking. Further to this, we have evaluated and discussed the current research published pertaining to stem cell tracking in both animal and human studies. Researchers across the globe are continuously working on ways to improve the techniques already in place, and to invent ways to combat limitations. It is, however, a new technology that requires further research and understanding. Many different types of peptides and different chemical coatings can be conjugated with SPIONs, and greater insights and understandings of the complex mechanisms that govern human functions are required to maximize the potential of the coatings. It is also still not fully clear which cytotoxic and hazardous effects the nanoparticles induce; consequentially, it will take time to allow them to be used in a clinical scenario. A greater understanding of the methods and strategies used to produce SPIONs with greater specificity and sensitivity are also needed. In summary, much work is still required in order to bring SPIONs into a clinical environment. Our understanding of many of the physiological mechanisms in the body has improved, our knowledge concerning the biology of stem cells has increased, and if research continues effectively, there is no doubt that nanoparticles, including SPIONS, will revolutionize clinical medicine.

\section{Disclosure}

The authors report no conflicts of interest in this work.

\section{References}

1. Becker AJ, McCulloch EA, Till JE. Cytological demonstration of the clonal nature of spleen colonies derived from transplanted mouse marrow cells. Nature. 1963;197:452-454.

2. Ghanbari H, de Mel A, Seifalian AM. Cardiovascular application of polyhedral oligomeric silsesquioxane nanomaterials: a glimpse into prospective horizons. Int J Nanomedicine. 2011;6:775-786.

3. Deans RJ, Moseley AB. Mesenchymal stem cells: biology and potential clinical uses. Exp Hematol. 2000;28(8):875-884.

4. de Mel A, Murad F, Seifalian AM. Nitric oxide: a guardian for vascular grafts? Chem Rev. 2011;111(9):5742-5767.

5. Bang OY, Lee JS, Lee PH, Lee G. Autologous mesenchymal stem cell transplantation in stroke patients. Ann Neurol. 2005;57(6):874-882.

6. Horwitz EM, Prockop DJ, Gordon PL, et al. Clinical responses to bone marrow transplantation in children with severe osteogenesis imperfecta. Blood. 2001;97(5):1227-1231.

7. Callera F, de Melo CM. Magnetic resonance tracking of magnetically labeled autologous bone marrow CD34+ cells transplanted into the spinal cord via lumbar puncture technique in patients with chronic spinal cord injury: CD34+ cells' migration into the injured site. Stem Cells Dev. 2007;16(3):461-466.

8. Wollert KC, Meyer GP, Lotz J, et al. Intracoronary autologous bone-marrow cell transfer after myocardial infarction: the BOOST randomised controlled clinical trial. Lancet. 2004;364(9429):141-148.

9. Peng XH, Qian X, Mao H, et al. Targeted magnetic iron oxide nanoparticles for tumor imaging and therapy. Int J Nanomedicine. 2008;3(3): 311-321.

10. Madani SY, Naderi N, Dissanayake O, Tan A, Seifalian AM. A new era of cancer treatment: carbon nanotubes as drug delivery tools. Int $J$ Nanomedicine. 2011;6:2963-2979.

11. Tan A, Yildirimer L, Rajadas J, De La Peña H, Pastorin G, Seifalian A. Quantum dots and carbon nanotubes in oncology: a review on emerging theranostic applications in nanomedicine. Nanomedicine (Lond). 2011;6(6):1101-1114.

12. LaConte L, Nitin N, Bao G. Magnetic nanoparticle probes. Mater Today. 2005;8(5 Suppl 1):32-38.

13. Reimer P, Balzer T. Ferucarbotran (Resovist): a new clinically approved RES-specific contrast agent for contrast-enhanced MRI of the liver: properties, clinical development, and applications. Eur Radiol. 2003;13(6):1266-1276. 
14. Neuberger T, Schöpf B, Hofmann H, Hofmann M, von Rechenberg B. Superparamagnetic nanoparticles for biomedical applications: possibilities and limitations of a new drug delivery system. $J$ Magn Magn Mater. 2005;293(1):483-496.

15. Lai CH, Yen TC, Ng KK. Molecular imaging in the management of cervical cancer. J Formos Med Assoc. 2012;111(8):412-420.

16. Lin MM, Kim do K, El Haj AJ, Dobson J. Development of superparamagnetic iron oxide nanoparticles (SPIONS) for translation to clinical applications. IEEE Trans Nanobioscience. 2008;7(4): 298-305.

17. Gindy ME, Prud'homme RK. Multifunctional nanoparticles for imaging, delivery and targeting in cancer therapy. Expert Opin Drug Deliv. 2009;6(8):865-878.

18. Rice HE, Hsu EW, Sheng H, et al. Superparamagnetic iron oxide labeling and transplantation of adipose-derived stem cells in middle cerebral artery occlusion-injured mice. AJR Am J Roentgenol. 2007;188(4): 1101-1108.

19. Harisinghani MG, Barentsz J, Hahn PF, et al. Noninvasive detection of clinically occult lymph-node metastases in prostate cancer. $N$ Engl J Med. 2003;348(25):2491-2499.

20. Rogers WJ, Basu P. Factors regulating macrophage endocytosis of nanoparticles: implications for targeted magnetic resonance plaque imaging. Atherosclerosis. 2005;178(1):67-73.

21. Moraes L, Vasconcelos-dos-Santos A, Santana FC, et al. Neuroprotective effects and magnetic resonance imaging of mesenchymal stem cells labeled with SPION in a rat model of Huntington's disease. Stem Cell Res. 2012;9(2):143-155.

22. Jung CW, Jacobs P. Physical and chemical properties of superparamagnetic iron oxide MR contrast agents: ferumoxides, ferumoxtran, ferumoxsil. Magn Reson Imaging. 1995;13(5):661-674.

23. Arai T, Kofidis T, Bulte JW, et al. Dual in vivo magnetic resonance evaluation of magnetically labeled mouse embryonic stem cells and cardiac function at 1.5 t. Magn Reson Med. 2006;55(1):203-209.

24. Guzman R, Uchida N, Bliss TM, et al. Long-term monitoring of transplanted human neural stem cells in developmental and pathological contexts with MRI. Proc Natl Acad Sci U S A. 2007;104(24): 10211-10216.

25. Jasmin, Torres AL, Nunes HM, et al. Optimized labeling of bone marrow mesenchymal cells with superparamagnetic iron oxide nanoparticles and in vivo visualization by magnetic resonance imaging. J Nanobiotechnology. 2011;9:4

26. Higuchi T, Anton M, Dumler K, et al. Combined reporter gene PET and iron oxide MRI for monitoring survival and localization of transplanted cells in the rat heart. J Nucl Med. 2009;50(7):1088-1094.

27. Welling MM, Duijvestein M, Signore A, van der Weerd L. In vivo biodistribution of stem cells using molecular nuclear medicine imaging. J Cell Physiol. 2011;226(6):1444-1452.

28. Berry CC, Wells S, Charles S, Aitchison G, Curtis AS. Cell response to dextran-derivatised iron oxide nanoparticles post internalisation. Biomaterials. 2004;25(23):5405-5413.

29. Jasmin, Torres AL, Jelicks L, de Carvalho AC, Spray DC, Mendez-Otero R. Labeling stem cells with superparamagnetic iron oxide nanoparticles: analysis of the labeling efficacy by microscopy and magnetic resonance imaging. Methods Mol Biol. 2012;906:239-252.

30. De Cuyper M, Joniau M. Magnetoliposomes. Formation and structural characterization. Eur Biophys J. 1988;15(5):311-319.

31. Syková E, Jendelová P. Magnetic resonance tracking of implanted adult and embryonic stem cells in injured brain and spinal cord. Ann N Y Acad Sci. 2005;1049:146-160.

32. Lalande C, Miraux S, Derkaoui SM, et al. Magnetic resonance imaging tracking of human adipose derived stromal cells within threedimensional scaffolds for bone tissue engineering. Eur Cell Mater. 2011;21:341-354

33. Cromer Berman SM, Walczak P, Bulte JW. Tracking stem cells using magnetic nanoparticles. Wiley Interdiscip Rev Nanomed Nanobiotechnol. 2011;3(4):343-355.
34. Jing XH, Yang L, Duan XJ, et al. In vivo MR imaging tracking of magnetic iron oxide nanoparticle labeled, engineered, autologous bone marrow mesenchymal stem cells following intra-articular injection. Joint Bone Spine. 2008;75(4):432-438.

35. Hu SL, Lu PG, Zhang LJ, et al. In vivo magnetic resonance imaging tracking of SPIO-labeled human umbilical cord mesenchymal stem cells. J Cell Biochem. 2012;113(3):1005-1012.

36. Chapon C, Jackson JS, Aboagye EO, Herlihy AH, Jones WA, Bhakoo KK. An in vivo multimodal imaging study using MRI and PET of stem cell transplantation after myocardial infarction in rats. $\mathrm{Mol}$ Imaging Biol. 2009;11(1):31-38.

37. Delcroix GJ, Jacquart M, Lemaire L, et al. Mesenchymal and neural stem cells labeled with HEDP-coated SPIO nanoparticles: in vitro characterization and migration potential in rat brain. Brain Res. 2009; $1255: 18-31$.

38. Mahmoudi M, Hosseinkhani H, Hosseinkhani M, et al. Magnetic resonance imaging tracking of stem cells in vivo using iron oxide nanoparticles as a tool for the advancement of clinical regenerative medicine. Chem Rev. 2011;111(2):253-280.

39. de Vries IJ, Lesterhuis WJ, Barentsz JO, et al. Magnetic resonance tracking of dendritic cells in melanoma patients for monitoring of cellular therapy. Nat Biotechnol. 2005;23(11):1407-1413.

40. Zhu J, Zhou L, XingWu F. Tracking neural stem cells in patients with brain trauma. N Engl J Med. 2006;355(22):2376-2378.

41. Arbab AS, Pandit SD, Anderson SA, et al. Magnetic resonance imaging and confocal microscopy studies of magnetically labeled endothelial progenitor cells trafficking to sites of tumor angiogenesis. Stem Cells. 2006;24(3):671-678.

42. Hsiao JK, Tai MF, Chu HH, et al. Magnetic nanoparticle labeling of mesenchymal stem cells without transfection agent: cellular behavior and capability of detection with clinical $1.5 \mathrm{~T}$ magnetic resonance at the single cell level. Magn Reson Med. 2007;58(4):717-724.

43. Bulte JW. Hot spot MRI emerges from the background. Nat Biotechnol. 2005;23(8):945-946.

44. Hoepken HH, Korten T, Robinson SR, Dringen R. Iron accumulation, iron-mediated toxicity and altered levels of ferritin and transferrin receptor in cultured astrocytes during incubation with ferric ammonium citrate. J Neurochem. 2004;88(5):1194-1202.

45. Arbab AS, Wilson LB, Ashari P, Jordan EK, Lewis BK, Frank JA. A model of lysosomal metabolism of dextran coated superparamagnetic iron oxide (SPIO) nanoparticles: implications for cellular magnetic resonance imaging. NMR Biomed. 2005;18(6):383-389.

46. Bulte JW, Kraitchman DL, Mackay AM, Pittenger MF. Chondrogenic differentiation of mesenchymal stem cells is inhibited after magnetic labeling with ferumoxides. Blood. 2004;104(10):3410-3412; author reply 3412 .

47. Amsalem Y, Mardor Y, Feinberg MS, et al. Iron-oxide labeling and outcome of transplanted mesenchymal stem cells in the infarcted myocardium. Circulation. 2007;116(Suppl 11):I38-I45.

48. Ricles LM, Nam SY, Sokolov K, Emelianov SY, Suggs LJ. Function of mesenchymal stem cells following loading of gold nanotracers. Int J Nanomedicine. 2011;6:407-416.

49. Mahmoudi M, Simchi A, Imani M, et al. A new approach for the in vitro identification of the cytotoxicity of superparamagnetic iron oxide nanoparticles. Colloids Surf B Biointerfaces. 2010;75(1):300-309.

50. Zhai Y, Han L, Wang P, et al. Superparamagnetic plasmonic nanohybrids: shape-controlled synthesis, TEM-induced structure evolution, and efficient sunlight-driven inactivation of bacteria. ACS Nano. 2011;5(11):8562-8570.

51. Hariharan V, Radhakrishnan S, Parthibavarman M, Dhilipkumar R, Sekar C. Synthesis of polyethylene glycol (PEG) assisted tungsten oxide (WO3) nanoparticles for L-dopa bio-sensing applications. Talanta. 2011;85(4):2166-2174.

52. Yaseneva P, Bowker M, Hutchings G. Structural and magnetic properties of Zn-substituted cobalt ferrites prepared by co-precipitation method. Phys Chem Chem Phys. 2011;13(41):18609-18614. 
53. El-Sherbiny IM, Smyth HD. Smart magnetically responsive hydrogel nanoparticles prepared by a novel aerosol-assisted method for biomedical and drug delivery applications. J Nanomater. 2011; 2011(2011):1-13.

54. Kim HM, Lee H, Hong KS, et al. Synthesis and high performance of magnetofluorescent polyelectrolyte nanocomposites as $\mathrm{MR} /$ nearinfrared multimodal cellular imaging nanoprobes. ACS Nano. 2011;5(10):8230-8240.

55. Ren J, Shen S, Pang Z, Lu X, Deng C, Jiang X. Facile synthesis of superparamagnetic $\mathrm{Fe}_{3} \mathrm{O}_{4} @$ Au nanoparticles for photothermal destruction of cancer cells. Chem Commun (Camb). 2011;47(42):11692-11694.

56. Zhou S, Chen Q. Synthesis and characterization of bracelet-like magnetic nanorings consisting of $\mathrm{Ag}-\mathrm{Fe}_{3} \mathrm{O}_{4}$ bi-component nanoparticles. Dalton Trans. 2011;40(34):8622-8629.

57. Niu H, Zhang D, Zhang S, Zhang X, Meng Z, Cai Y. Humic acid coated $\mathrm{Fe}_{3} \mathrm{O}_{4}$ magnetic nanoparticles as highly efficient Fenton-like catalyst for complete mineralization of sulfathiazole. J Hazard Mater. 2011;190(1-3):559-565.

58. Moon JW, Rawn CJ, Rondinone AJ, et al. Large-scale production of magnetic nanoparticles using bacterial fermentation. $J$ Ind Microbiol Biotechnol. 2010;37(10):1023-1031.

59. Nidhin M, Indumathy R, Sreeram KJ, Nair BU. Synthesis of iron oxide nanoparticles of narrow size distribution on polysaccharide templates. Bulletin of Material Science. 2008;31(1):93-96.

60. Du L, Chen J, Qi Y, et al. Preparation and biomedical application of a non-polymer coated superparamagnetic nanoparticle. Int $J$ Nanomedicine. 2007;2(4):805-812.

61. Yu WW, Falkner JC, Yavuz CT, Colvin VL. Synthesis of monodisperse iron oxide nanocrystals by thermal decomposition of iron carboxylate salts. Chem Commun (Camb). 2004;(20):2306-2307.

62. Jiang W, Yang HC, Yang SY, et al. Preparation and properties of superparamagnetic nanoparticles with narrow size distribution and biocompatible. J Magn Magn Mater. 2004;283(2-3):210-214.
63. Gupta AK, Wells S. Surface-modified superparamagnetic nanoparticles for drug delivery: preparation, characterization, and cytotoxicity studies. IEEE Trans Nanobioscience. 2004;3(1):66-73.

64. McClelland R, Wauthier E, Tallheden T, Reid LM, Hsu E. In situ labeling and magnetic resonance imaging of transplanted human hepatic stem cells. Mol Imaging Biol. 2011;13(5):911-922.

65. van Buul GM, Kotek G, Wielopolski PA, et al. Clinically translatable cell tracking and quantification by MRI in cartilage repair using superparamagnetic iron oxides. PLoS One. 2011;6(2):e17001.

66. Kim T, Momin E, Choi J, et al. Mesoporous silica-coated hollow manganese oxide nanoparticles as positive T1 contrast agents for labeling and MRI tracking of adipose-derived mesenchymal stem cells. J Am Chem Soc. 2011;133(9):2955-2961.

67. Meng X, Seton HC, Lu le T, Prior IA, Thanh NT, Song B. Magnetic CoPt nanoparticles as MRI contrast agent for transplanted neural stem cells detection. Nanoscale. 2011;3(3):977-984.

68. Henning TD, Sutton EJ, Kim A, et al. The influence of ferucarbotran on the chondrogenesis of human mesenchymal stem cells. Contrast Media Mol Imaging. 2009;4(4):165-173

69. Wang HH, Wang YX, Leung KC, et al. Durable mesenchymal stem cell labelling by using polyhedral superparamagnetic iron oxide nanoparticles. Chemistry. 2009;15(45):12417-12425.

70. Reddy AM, Kwak BK, Shim HJ, et al. In vivo tracking of mesenchymal stem cells labeled with a novel chitosan-coated superparamagnetic iron oxide nanoparticles using 3.0T MRI. J Korean Med Sci. 2010;25(2): 211-219.

71. Loebinger MR, Kyrtatos PG, Turmaine M, et al. Magnetic resonance imaging of mesenchymal stem cells homing to pulmonary metastases using biocompatible magnetic nanoparticles. Cancer Res. 2009;69(23): 8862-8867.

72. Lee ES, Chan J, Shuter B, et al. Microgel iron oxide nanoparticles for tracking human fetal mesenchymal stem cells through magnetic resonance imaging. Stem Cells. 2009;27(8):1921-1931.
International Journal of Nanomedicine

\section{Publish your work in this journal}

The International Journal of Nanomedicine is an international, peerreviewed journal focusing on the application of nanotechnology in diagnostics, therapeutics, and drug delivery systems throughou the biomedical field. This journal is indexed on PubMed Central,

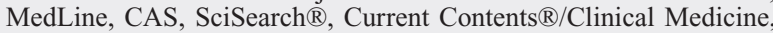

\section{Dovepress}

Journal Citation Reports/Science Edition, EMBase, Scopus and the Elsevier Bibliographic databases. The manuscript management system is completely online and includes a very quick and fair peer-review system, which is all easy to use. Visit http://www.dovepress.com/ testimonials.php to read real quotes from published authors. 